\title{
National Medication Utilization Evaluation Program in Saudi Arabia
}

\author{
Yousef Ahmed Alomi* ${ }^{*}$, The \\ Former General Manager of General Adminis- \\ tration of Pharmaceutical Care and Head, \\ National Clinical pharmacy, and Pharmacy \\ Practice and Pharmacy R \& D Administration, \\ $\mathrm{MOH}$, Riyadh, Saudi Arabia. \\ Abeer Hussin Almasoudi, \\ Director, Administration of Research and \\ Studies, Ministry of Health, Tabuk, Saudi \\ Arabia.
}

\section{Correspondence:}

Dr. Yousef Ahmed Alomi, The Former General Manager of General Administration of Pharmaceutical Care, The Past Head, National Clinical pharmacy and pharmacy practice, The Past Head, Pharmacy R and D Administration, Ministry of Health, Riyadh, SAUDI ARABIA

Phone no: +966 504417712

E-mail:yalomi@gmail.com
Received: 03-03-2019;

Accepted: 04-05-2019

Copyright: (C) the author(s), publisher and licensee International Journal of Pharmacology and Clinical Sciences. This is an open-access article distributed under the terms of the Creative Commons Attribution Non-Commercial License, which permits unrestricted non-commercial use, distribution, and reproduction in any medium, provided the original work is properly cited.

This is an open access article distributed under the terms of the Creative Commons Attribution-NonCommercial-ShareAlike 4.0 License

Access this article online

\begin{tabular}{|c|c|}
\hline & www.ijpcs.net \\
\hline & DOI: \\
\hline
\end{tabular}

\begin{abstract}
The national Medication Utilization Evaluation Program at the Ministry of health in Saudi Arabia with complimentary of physician order techniques is new system founded in the Kingdom of Saudi Arabia. The programming part of pharmacy strategic planning and national pharmacy practice at health care services at the Ministry of health. The Medication Utilization Evaluation program started with evidence-based medicine guidelines. The new project of Medication Utilization Evaluation physician order was one the outcome of the program. The program steps development through central committee by Pharmacy department at the most prominent hospital crossover regions in Saudi Arabia. The project is complementary of pharmaceutical concept and alerting system of misuse of medications and subsequences medication-related problems and avoids the unnecessary economic burden on the healthcare system. The new national Medication Utilization Evaluation project is new in Saudi Arabia, Gulf, and Middle East counties.
\end{abstract}

Keywords: Medication, Utilization, Evaluation, Ministry of health in Saudi Arabia, Ministry of Health, Saudi Arabia.

\section{INTRODUCTION}

The medication use evaluation program is very beneficial system of awareness of misuse of medications and economic burden of healthcare services in Saudi Arabia. ${ }^{[1,2]}$ The American of Health System Pharmacist (ASHP) and the Society of Hospital Pharmacists of Australia (SHPA) released the standard of medications use evaluation program. ${ }^{[3,4]}$ The General Administration of Pharmaceutical care implementation, the national medication use evaluation program stated in 2014 among several national pharmacy practice program at Ministry of Health institutions. ${ }^{[5,6]}$ The program followed the previous both international hospital societies. Several studies showed the percentage of implementation of medications use evaluation at Saudi Arabia. The program found at $60 \%$ of hospitals, $41.4 \%$ of clinical pharmacist activities, and only $36 \%$ hospital had clinical pharmacist specialized in Medications use Evaluation. ${ }^{[6,7]}$ In addition, the DUE committee founded at $43.2 \%$ hospital only, and $52.6 \%$ of implementation of DUE standard. ${ }^{[6,8]}$ The new updating national medication use evaluation program with physician order techniques is seldom find in the Saudi Arabia, Gulf and Middle East countries. The goal of the minireview to explore the National Medication Utilization Evaluation Program at Ministry of health in Saudi Arabia.

\section{Medication Use Evaluation order in Saudi Arabia}

The Medication Use Evaluation physician order form consisted of patient demographic data, the diagnosis, criteria's for indications, Critical (Process) Indicators, the general dosing for each indications, the adjusting dose if, the monitoring parameters, the duration of therapy, time of adminstration of medications, and prescriber name and clinical pharmacist for follow up. The form may quickly convert to the electronic format in the computer pharmacy system as explored in appendix 1, appendix 2, appendix 3, and appendix 4. The forms missed the Complications standards, Critical Preventative/Responsive Management, and Outcome Measures. All missing points should cover through clinical pharmacist follow up drug therapy. Another method of physician order consisted of treatment of diseases as clinical pathway as explored in other references.

\section{SWOT Analysis}

The Strength, Weakness, Opportunities, and Threats (SWOT) analysis used for the project. The strong points of the project were, easy way to implement Medication Use Evaluation program it is easy way to collect the data of Medication Use Evaluation, it is a clinical pathway of Medication Use Evaluation, educational tool for new staff; it fit the accreditation and requirements of national organizations of accreditation health care institutions, it is control of hospital formulary and prevents miss-use if medications. The forms not covered all medications, and it was not an electronic format, and not covered Complications standards, Critical Preventative/Responsive Management, and Outcome Measures. The opportunities points were part of accreditation requirements, and threads points were it not followed by healthcare staff, the new updating of the Medication Use Evaluation. 
Implementations steps of

Medication Use Evaluation Program at Ministry of Health Institutions

The central committee of medication use evaluation implemented the program through the following steps: Identification of drug use process of evaluation. Target areas for evaluation may include individual drugs, drug classes, or Therapeutic indication which includes: Drugs known to be associated with adverse event or poor patient outcome, Drug used in high risk patient, Drug with high-unit or high volume cost, Drugs or processes where its suboptimal use is likely to have negative effect on patient outcomes or system cost, and Adverse medication event as a sign of treatment. Assembling the medication use team, Approval of the study from director of pharmacy, Development of criteria and measurement instruments, Data collection (retrospective / concurrent / prospective), Evaluation with pre-determined criteria and analysis of the results, Reporting and having a feedback from those concerned, Designing and implementation of intervention strategies, and Reassessment and revision of problem. The general administration of pharmaceutical care at $\mathrm{MOH}$ sent a memo in early May 2014 to each region to started and implement the program

\section{Implementations steps of Medication Use Evaluation physician Oder}

It is evidence-based medication use evaluations at cross over of hospital at Ministry of Health in Kingdom of Saudi Arabia. The Medication Use Evaluation physician Oder based on evidence based on current and update literatures and American Food and Drug Administration
(FDA), and Saudi Food and Drug Authority (SFDA) (3)(4). It designed through Medication Use Evaluation committee and headed by the author. The committee consisted of head of national drug information center, drug information pharmacist or Medication Use Evaluation from each regions overall kingdom of Saudi Arabia. The first draft finished by the committee members and revised by the first author and other members. The committee made several discussion and final agreement. Each of the head of hospital pharmacy submit to the pharmacy and therapeutic for revision and final approval. The Medication Use Evaluation physician order implemented through several education session with hospital staff. The manual physician order sent to information technology to convert as electronic physicians order entry for each institution.

\section{CONCLUSION}

The National Medication Utilization Evaluation Program at Ministry of health in Saudi Arabia with new system of physician order is new Saudi Arabia and first services in Gulf and Middle East counties. It had several advantages for clinical and economic patients and healthcare services outcomes in Kingdom of Saudi Arabia.

\section{ACKNOWLEDGMENT}

None.

\section{CONFLICT OF INTEREST}

None.

\section{ABBREVIATIONS}

ASHP: American of Health System Pharmacist; SHPA: Society of Hospital Pharmacists of
Australia; SWOT: Strength, Weakness, Opportunities, and Threats; KSA: Kingdom of Saudi Arabia; MOH: Ministry of Health.

\section{ORCID ID}

Yousef Ahmed Alomi (D) https://orcid. org/0000-0003-1381-628X

\section{REFERENCES}

1. Alomi YA. Human albumin solutions utilization pattern in Riyadh Central Hospital, Riyadh, Saudi Arabia. In: ACCP Annual Meeting, October 2006, USA.

2. Alangari AA, Abutaleb MH, Albarraq AA, Al-Dhowailie AA. Intravenous immunoglobulin utilization in a tertiary care teaching hospital in Saudi Arabia. Saudi Med J 2008; 2008;29(7):2-6.

3. American Society of Health-System Pharmacists. ASHP guidelines on medication-use evaluation. Am J Heal Pharm. 1996;53:1953-5.

4. Doherty P, Kirsa S, Chao S, Wiltshire S, McKnight D, Maxwell D, et al. SHPA standards of practice for drug use evaluation in Australian hospitals. J Pharm Pract Res. 2004;34(3):220-3.

5. Alomi YA. National Pharmacy Practice Programs at Ministry of Health in Saudi Arabia. J Pharm Pharm Scien. 2015;1(2):17-8

6. Alomi YA, Almudaiheem HY, Alsharari A. National Survey of Drug Information Centers Practice in Saudi Arabia: Medication-Use Evalaution at Ministery of Health hospitals. J Pharmacovigi. 2017;5(5):1-4.

7. Yousef Ahmed Alomi, Saeed Jamaan Alghamdi RAA. National Survey of Pharmacy Practice at MOH Hospitals in Saudi Arabia 2016-2017 : Clinical Pharmacy Services. J Pharm Pr Community Med. 2018;4(1):1S-8S.

8. Alomi YA, Alghamdi SJ, Alattyh RA, Shorog E, Alshahran A, Alasmary S, Alenazi H, Almutairi A AM. National Survey of Pharmacy Practice At Ministry of Health Hospitals in Saudi Arabia 2016: Pharmacy Management and Resources. J Pharm Pr Community Med. 2018;(5):S54-9. 


\section{Hospital \\ Pharmaceutical Care Department Region \\ Physician Order Form}

(Please fill all applicable information and stick it on patient profile, and forward the copy to the Pharmacy Department within $24 \mathrm{hrs}$.)

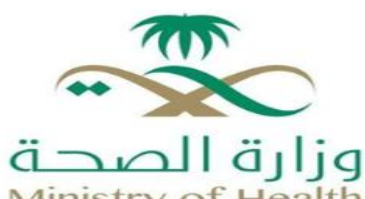

Ministry of Health

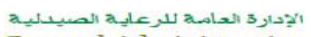
General Administration of Pharmaceutical Care

\section{COLISTIN ORDER FORM(1)(2)(3)}

(Drug Utilization Evaluation Program)

Patient's Name

File No

Age:

Gender $\square$ Male $\square$ Female

Wt.

$\mathrm{kg}$.

Allergy:

Colistin Indication: Treatment of acute or chronic infections due to sensitive strains of certain gram-negative bacilli (particularly Pseudomonas aeruginosa) which are resistant to other antibacterials or in patients allergic to other antibacterials

Review patient allergies prior to prescribing/administering medications.

- Select appropriate antibiotic as determined Antibiotic Guidelines, after collecting specimen for Gram stain and C/S

\section{$\square$ Diagnosis}

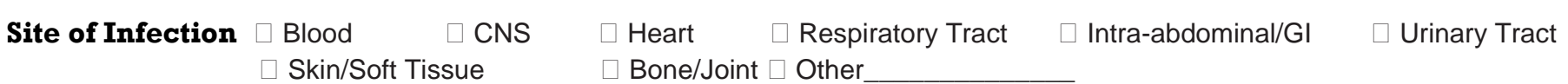

\section{Type of Infection $\square$ Community Associated $\square$ Hospital care Associated}

\section{Type of Therapy: $\square$ Emperical $\square$ Specific}

\section{$\square \mathrm{C} / \mathrm{s} \quad \square$ Organism}

Sensitivity: Resistant to

\section{$\mathrm{CrCl}$ :}

$\mathbf{m l} / \mathbf{m i n}$.

\section{Colistin}

1) Colistin Base

a) Colistin base $1 \mathrm{mg}$ = colistimethate

sodium $2.4 \mathrm{mg}$

b) Colistin base $1 \mathrm{mg}=30,000$

International Units potency

2) Colistimethate Sodium (CMS)

a) Colistimethate sodium $1 \mathrm{mg}=12,500$

International Units potency

$1 \mathrm{MU}=80 \mathrm{mg} \mathrm{CMS}=33 \mathrm{mg}$ colistin base

\begin{tabular}{|c|c|c|c|}
\hline Dose & Routs & Frequency & duration \\
\hline $\begin{array}{l}(\mathrm{adult}: 2.5 \mathrm{mg}-5 \mathrm{mg} \text { base } / \mathrm{kg} / \mathrm{day} \\
(\mathrm{C})\end{array}$ & \multirow{2}{*}{$\square$ IV $\square$ IM } & \multirow{2}{*}{$\begin{array}{l}\text { Gevery } 6 \text { hours } \\
\text { Gevery } 8 \text { houres } \\
\text { Gevery } 12 \text { houres }\end{array}$} & \\
\hline $\begin{array}{l}\text { ( pediatric2.5mh-5mg base/kg/day } \\
(\mathrm{C})\end{array}$ & & & \\
\hline
\end{tabular}

Dosing adjesment in renal Impairment:

$\square \mathrm{CrCl}$ 50-79 mL/minute: $2.5-3.8 \mathrm{mg} / \mathrm{kg}$ Cloistin base in two divided doses daily.

$\square \mathrm{CrCl} 30$ to $49 \mathrm{~mL} / \mathrm{minute}: 2.5 \mathrm{mg} / \mathrm{kg}$ Cloistin base once or in two divided doses daily.

$\square \mathrm{CrCl} 10-29 \mathrm{~mL} / \mathrm{minute}: 2.5 \mathrm{mg} / \mathrm{kg}$ Cloistin base every 36 hours.

Note: $\mathrm{CrCl}$ calculated using the Cockcroft-Gault equation

\section{$\square$ New Order}

\section{$\square$ Renew Order}

Date:

Time of Antibiotic order :

Time of Administration

Physician's Requesting :

$\square$ Consultants

$\square$ Registrar

Senior Registrar

$\square$ Specialist

$\square$ Resident

$\square$ Intern

\section{Clinical Pharmacist Follow up and Comment:}

\section{References}

1. Micromedex Solution App. Colistimethate Sodium. IBM Corporation; 2018

2. Labuschagne Q, Schellack N, Gous A, Bronkhorst E, Schellack G, van Tonder L, et al. COLISTIN: adult and paediatric guideline for South Africa, 2016. South African J Infect Dis [Internet]. 2016;31(1):3-7. Available from: http://www.tandfonline.com/doi/full/10.1080/23120053.2016.1 144285

3. Messina AP, Brink AJ, Richards GA, van Vuuren S. Opportunities to optimise colistin stewardship in hospitalised patients in South Africa: Results of a multisite utilisation audit. South African Med J. 2018;108(1):28-32. 


\begin{tabular}{|c|c|c|}
\hline & 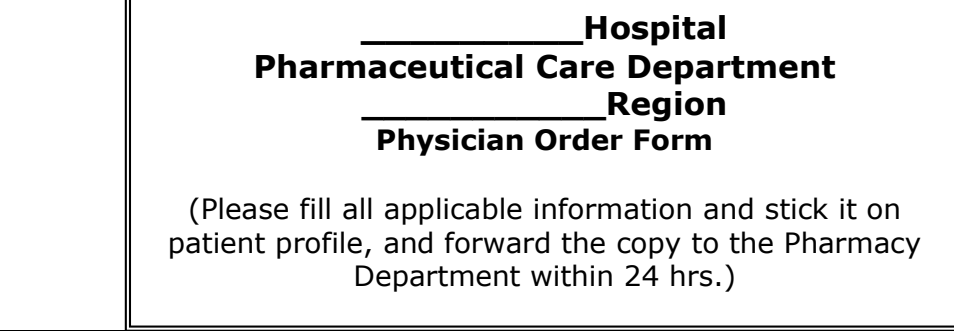 & 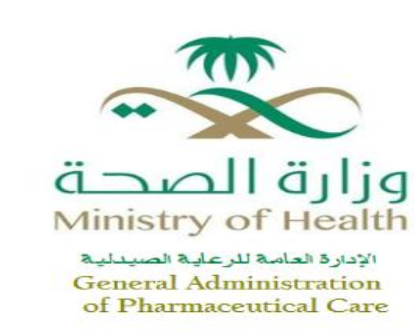 \\
\hline \multicolumn{3}{|c|}{$\begin{array}{l}\text { TIGECYCLINE ORDER FORM }(1)(2)(3)(4)(5) \\
\text { (Drug Utilization Evaluation Program) }\end{array}$} \\
\hline $\begin{array}{l}\text { Patient's Name } \\
\text { Allergy: }\end{array}$ & File No__ Age:__ Gender $\square$ Male $\square$ Female & Wt.:_ $\mathrm{kg}$. \\
\hline Tigecycline Indication: & \multicolumn{2}{|c|}{$\begin{array}{l}\square \text { Intra-abdominal infections, complicated OR } \\
\square \text { Skin/skin structure infections, complicated AND infected by } \\
\text { ESBL-producing strains or polymicrobial MDR infections (excluding Pseudomonas spp) }\end{array}$} \\
\hline \multicolumn{3}{|c|}{$\begin{array}{l}\text { Review patient allergies prior to prescribing/administering medications. } \\
\text { - Select appropriate antibiotic as determined Antibiotic Guidelines, after collecting specimen for Gram stain and C/S }\end{array}$} \\
\hline
\end{tabular}

\section{$\square$ Diagnosis}

Site of Infection $\square$ Blood $\quad \square$ Respiratory Tract $\quad \square$ Intra-abdominal/Gl $\quad \square$ Skin/Soft Tissue $\square$ Other

Type of Infection $\square$ Community Ässociated $\square$ Hospital care Ässociated

Type of Therapy: $\square$ Emperical $\square$ Specific

\section{$\square \mathrm{C} / \mathrm{S} \quad \square$ Organism}

Sensitivity: Resistant to

\section{Tigecycline}

\begin{tabular}{|c|c|c|c|}
\hline Dose & Routs & Frequency & duration \\
\hline $\begin{array}{l}\square \text { adult Initial: } 100 \mathrm{mg} \text { as a single } \\
\text { dose; Maintenance dose: } 50 \mathrm{mg}\end{array}$ & & & \\
\hline $\begin{array}{l}\square \text { pediatric } \\
\square \text { Children } 8 \text { to } 11 \text { years: } \\
1.2 \mathrm{mg} / \mathrm{kg} / \text { dose; max. dose: } 50 \mathrm{mg} \\
\square \text { Children } 12-18 \text { years: } 50 \mathrm{mg} \\
\text { ( }) \text { ) }\end{array}$ & 口IV & Devery 12 hours & $\begin{array}{l}\square 7 \text { days } \\
\square 14 \text { days }\end{array}$ \\
\hline
\end{tabular}

\section{New Order}

\section{Renew Order}

\begin{tabular}{lll} 
Date: & Time of Antibiotic order : & Time of Administration $\square$ \\
\hline
\end{tabular}

Physician's Requesting :
$\square$ Consultants
$\square$ Registrar
口 Senior Registrar
$\square$ Specialist
$\square$ Resident
$\square$ Intern

\section{Clinical Pharmacist Follow up and Comment:}

References

1. Micromedex Solution App. Colistimethate Sodium. IBM Corporation; 2018.

2. Stein GE, Craig WA. Tigecycline : A Critical Analysis. CID. 2006;43(July) 3. Brink AJ, Bizos D, Boffard KD, Feldman C, Grolman DC, Pretorius J, et al. Guideline: Appropriate use of tigecycline. South African J Surg. 2010;50(1):388-
94.

4. Brink AJ, Bizos D, Boffard KD, Feldman C, Grolman DC, Pretorius J, et al. Guideline summary: Appropriate use of tigecycline. South African J Surg. 2012;50(1):20-1.

5. Shen F, Han Q, Xie D, Fang M, Zeng H, Deng Y. Efficacy and safety of tigecycline for the treatment of severe infectious diseases: An updated metaanalysis of RCTs. Int J Infect Dis [Internet]. 2015;39:25-33. Available from: http://dx.doi.org/10.1016/j.ijid.2015.08.009 


\section{Hospital \\ Pharmaceutical Care Department Region \\ Physician Order Form}

(Please fill all applicable information and stick it on patient profile, and forward the copy to the Pharmacy Department within 24 hrs.)

\section{VANCOMYCIN ORDER FORM(1)(2) \\ (Drug Utilization Evaluation Program)}

Patient's Name_ale No_
Allergy:__ Age:

$\square$ Staphylococcal infections:Srious or severe infections (eg, septicemia, bone infections, lower respiratory tract infections, skin and skin structure infections) caused by susceptible strains of methicillin-resistant (beta-lactam-resistant) staphylococci; empiric therapy of infections when methicillin-resistant staphylococci are suspected

\section{$\square$ Other(}

Review patient allergies prior to prescribing/administering medications.

- Select appropriate antibiotic as determined Antibiotic Guidelines, after collecting specimen for Gram stain and C/S

\section{$\square$ Diagnosis}

Site of Infection

$\square$ Blood $\square$ CNS
$\square$ Skin/Soft Tissue

Type of Infection $\square$ Community Associated

$\square$ Heart $\quad \square$ Respiratory Tract $\quad \square$ Intra-abdominal/GI $\quad \square$ Urinary Tract
$\square$ Bone/Joint $\square$ Other

Hospital care Associated

Type of Therapy: $\square$ Emperical $\square$ Specific

$\square \mathrm{C} / \mathrm{s} \square$ Organism

Sensitivity: Resistant to

\section{CrCl:}

eGFR:

\section{$\mathrm{ml} / \mathrm{min}$.}

$\mathrm{mL} / \mathrm{minute}$ per $1.73 \mathrm{~m} 2$

\begin{tabular}{|c|c|c|c|}
\hline $\begin{array}{l}\text { Dose } \\
\text { (to achieve sustained trough levels of } 15-20 \mathrm{mg} / \mathrm{L} \text { ) }\end{array}$ & Routs & Frequency & duration \\
\hline $\begin{array}{l}\text { adult: } 10-15 \mathrm{mg} / \mathrm{kg} \text { actual body weight every } \\
8-12 \text { hours ( }\end{array}$ & \multirow{2}{*}{$\begin{array}{l}\text { IV } \\
\text { infusion } \\
\text { over at } \\
\text { least } 2 \\
\text { hours }\end{array}$} & \multirow{2}{*}{$\begin{array}{l}\text { पevery } 6 \text { hours } \\
\text { Gevery } 8 \text { hours } \\
\text { पevery } 12 \text { houres }\end{array}$} & \multirow{2}{*}{$\begin{array}{l}\square 7 \text { days } \\
\square 14 \text { days }\end{array}$} \\
\hline $\begin{array}{l}\square \text { pediatric: } 10 \mathrm{mg} / \mathrm{kg} / \text { dose every } 6 \text { hrs. } \\
(\max : 2,000 \mathrm{mg} / \text { dose }) \text { (_) }\end{array}$ & & & \\
\hline
\end{tabular}

Dosing adjesment in renal Impairment: see the attached table

\section{$\square$ New Order}

\section{Date:}

Physician's Requesting :

\section{$\square$ Renew Order}

Time of Antibiotic order :
Time of Administration

2
$\square$ Consultants
$\square$ Registrar
口 Senior Registrar
$\square$ Specialist
$\square$ Resident
$\square$ Intern

\section{Clinical Pharmacist Follow up and Comment:}

Refrences

1. American Society of Health-System. Therapeutic monitoring of vancomycin in adult patients : A consensus review of the American Diseases Society of America, and the Society. Am J Heal Pharm. 2009;66(1):82-98.

Rybak MJ, Lomaestro BM, Rotschafer JC, Moellering RC, Craig WA, Billeter M, et al. Vancomycin Therapeutic Guidelines: A Summary of Consensus Recommendations from the Infectious Diseases Society of America, the American Society of Health-System Pharmacists, and the Society of Infectious Diseases Pharmacists. Clin Infect Dis [Internet]. 2009;49(3):325-7. Available from:

https://academic.oup.com/cid/article-lookup/doi/10.1086/600877 


\begin{tabular}{|c|c|}
\hline $\begin{array}{l}\text { Pharmaceutical Care Department } \\
\qquad \begin{array}{c}\text { Region } \\
\text { DUE Program) }\end{array} \\
\text { Physician Order Form } \\
\text { (Please fill all applicable information and stick it on } \\
\text { patient profile, and forward the copy to the Pharmacy } \\
\text { Department within } 24 \text { hrs) }\end{array}$ & و الم \\
\hline
\end{tabular}

Note: Vancomycin levels should be monitored in patients with any renal impairment:

\section{Vancomycin Initial Dosage Regimens for Adults Patients With Impaired Renal Function (Golightly 2013)}

\begin{tabular}{|c|c|c|c|c|}
\hline \multirow{2}{*}{ eGFR (mL/minute per $1.73 \mathrm{~m} 2)$} & \multicolumn{4}{|l|}{ Actual Body Weight } \\
\hline & $<60 \mathrm{~kg}$ & 60 to $80 \mathrm{~kg}$ & 81 to $100 \mathrm{~kg}$ & $>100 \mathrm{~kg}$ \\
\hline \multicolumn{5}{|c|}{$\begin{array}{l}\text { aCheck a random vancomycin level in } 24 \text { hours after the dose. If random level is } \leq 20 \mathrm{mcg} / \mathrm{mL} \text {, repeat the dose. If random level is } \\
>20 \mathrm{mcg} / \mathrm{mL} \text {, do not re-dose; repeat random level in } 12 \text { hours. }\end{array}$} \\
\hline$>90$ & $750 \mathrm{mg}$ every 8 hours & $1,000 \mathrm{mg}$ every 8 hours & $1,250 \mathrm{mg}$ every 8 hours & $1,500 \mathrm{mg}$ every 8 hours \\
\hline 50 to 90 & 750 mg every 12 hours & $\begin{array}{c}1,000 \text { mg every } 12 \\
\text { hours }\end{array}$ & $\begin{array}{c}1,250 \mathrm{mg} \text { every } 12 \\
\text { hours }\end{array}$ & $1,000 \mathrm{mg}$ every 8 hours \\
\hline 15 to 49 & 750 mg every 24 hours & $\begin{array}{l}1,000 \text { mg every } 24 \\
\text { hours }\end{array}$ & $\begin{array}{l}1,250 \text { mg every } 24 \\
\text { hours }\end{array}$ & $\begin{array}{l}1,500 \text { mg every } 24 \\
\text { hours }\end{array}$ \\
\hline$<15 a$ & $\underline{750 \mathrm{mg}}$ & $1,000 \mathrm{mg}$ & $1,250 \mathrm{mg}$ & $\underline{1,500 \mathrm{mg}}$ \\
\hline
\end{tabular}

Reference:

Golightly LK, Teitelbaum I, Kiser TH, et al. (eds.) Renal Pharmacotherapy. Springer Science, New York. 2013 


\begin{tabular}{|c|c|c|c|}
\hline \multicolumn{3}{|c|}{\begin{tabular}{||c|c|} 
Pharmaceutical Care Department \\
Region \\
\cline { 2 - 2 } \\
Physician Order Form \\
(Please fill all applicable information and stick it on \\
patient profile, and forward the copy to the Pharmacy \\
Department within 24 hrs.)
\end{tabular}} & ר) \\
\hline \multicolumn{4}{|c|}{$\begin{array}{c}\text { ALBUMIN ORDER FORM(1)(2)(3)(4) } \\
\text { (Drug Utilization Evaluation Program) } \\
\end{array}$} \\
\hline \multicolumn{4}{|c|}{$\begin{array}{l}\text { Patient's Name___ : } \\
\text { Allergy: }\end{array}$} \\
\hline \multicolumn{4}{|c|}{ 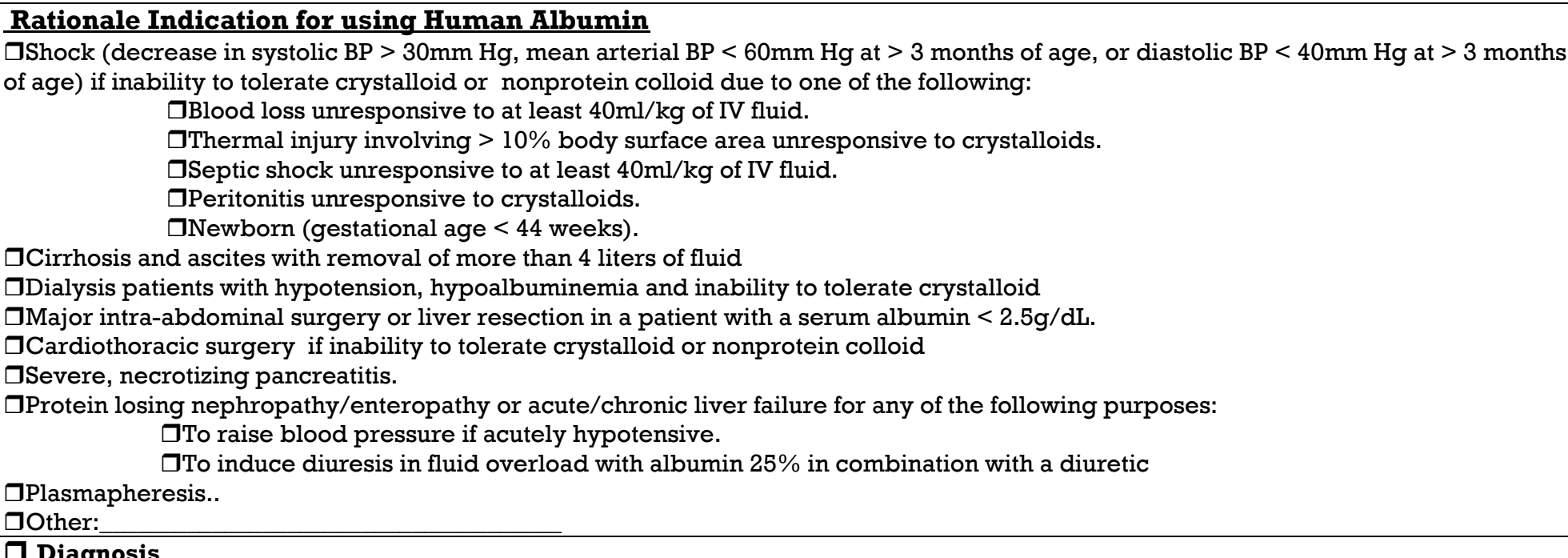 } \\
\hline \multicolumn{4}{|c|}{$\begin{array}{l}\text { 口Total Serum Protein: } \\
\square \text { पSerum Albumin level: }\end{array}$} \\
\hline \multicolumn{4}{|c|}{$\begin{array}{l}\text { May be considered after inadequate response to crystalloid therapy and when nonprotein colloids are contraindicated. The volume } \\
\text { administered and the speed of infusion should be adapted to individual response }\end{array}$} \\
\hline \multirow{2}{*}{ Albumin to use } & $\begin{array}{l}\text { 口Albumin } 5 \% \ldots \ldots \ldots \ldots . . . \mathrm{ml} \text {; Give IV every...............hrs } \mathrm{x} \\
\text {........... Doses. } \\
\text { Note: Albumin } 5 \% \text { is dosed in milliliters. }\end{array}$ & $\begin{array}{l}5 \% \text { should be } \\
\text { intravascular }\end{array}$ & $\begin{array}{l}\text { in hypovolemic patients or } \\
\text { leted patients }\end{array}$ \\
\hline & $\begin{array}{l}\text { DAlbumin } 25 \% \ldots \ldots \ldots \ldots \ldots \ldots . . . \text { gram(s); infuse } \\
\text { over...............hrs. } \\
\text { Note: Albumin } 25 \% \text { is dosed in grams. }\end{array}$ & $\begin{array}{l}25 \% \text { should } \mathrm{b} \\
\text { sodium intake }\end{array}$ & $\begin{array}{l}\text { in patients in whom fluid and } \\
\text { be minimized. }\end{array}$ \\
\hline \multicolumn{4}{|c|}{ 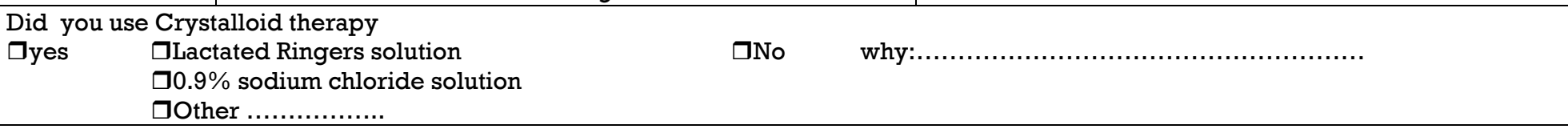 } \\
\hline \multicolumn{4}{|c|}{ 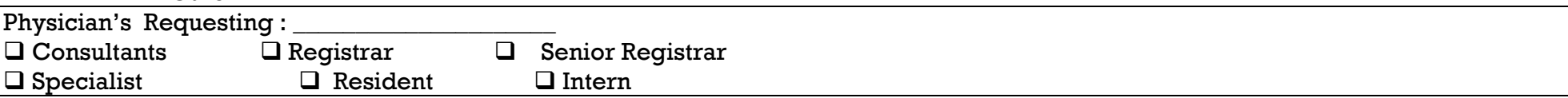 } \\
\hline $\begin{array}{ll}\text { Clinical Phat } \\
\text { References: } \\
\text { 1. } \quad \text { Micromec } \\
\text { 2. } \quad \text { Vermeule } \\
& \text { Solutions. } \\
\text { 3. } & \text { Boldt J. Us } \\
4 . \quad \text { Yasumura } \\
\end{array}$ & $\begin{array}{l}\text { acist Follow up and Comment: } \\
\text { Solution App. Colistimethate Sodium. IBM Corporation; } 2018 . \\
\text { Colloid N et. al. A Paradigm for Consensus: The University Hospital Consort } \\
\text { Intern Med. 1995;155:373-9. } \\
\text { albumin: An update. Br J Anaesth. 2010;104(3):276-84. } \\
\text { Makino S, Matsumoto M, Kono T, Kino S, Tanaka A, et al. Evidence-based Gui } \\
\text { Cell Therapy. Japanese J Transfus Cell Ther [Internet]. 2017;63(5):641-63. }\end{array}$ & Guidelines for th & $\begin{array}{l}\text { Hbumin,Nonprotein Colloid, and Crystalloid } \\
\text { Products Japan Society of Transfusion }\end{array}$ \\
\hline
\end{tabular}

